DOI https://doi.org/10.18551/rjoas.2021-01.09

\title{
THE EFFECT OF NITROGEN DOSAGE ON N EFFICIENCY AND PROTEIN CONTENT IN POTATOES
}

\author{
Rosyidah Anis* \\ Department of Agrotechnology, Faculty of Agriculture, University of Islam Malang, Indonesia \\ Khoiriyah Nikmatul, Siswadi Bambang \\ Department of Agribusiness, Faculty of Agriculture, University of Islam Malang, Indonesia \\ *E-mail: ard@unisma.ac.id
}

\begin{abstract}
The availability of nutrients in the soil, especially nitrogen $(\mathrm{N})$, significantly affects the production and quality of potato tubers. Case $\mathrm{N}$ is a very dynamic nutrient. Uncontrolled application of $\mathrm{N}$ fertilizer causes low farm efficiency and even results in environmental pollution. This study aims to analyze $\mathrm{N}$ fertilizer use's efficiency and analyze the optimum dose that can increase the protein content of potato tubers. Field trials were carried out on farmers' land in the village of Sumberejo, Batu, East Java, Indonesia, at an altitude of 710 above sea level. The study used a randomized block design with four $\mathrm{N}$ dosage treatments, namely: $40,80,120,160 \mathrm{~N} \mathrm{~kg} \mathrm{ha}{ }^{-1}$. The treatment was repeated six times, with each replication consisting of 5 plant samples. $\mathrm{N}$ fertilizer source comes from $\mathrm{ZA}$, which is applied two times, at the time of planting and on the 35th day after planting. The results showed that $\mathrm{N}$ fertilizer's application at various doses had a significant effect on $\mathrm{N}$ nutrient efficiency and protein content in potato tubers. Giving a dose of $\mathrm{N}$ of $120 \mathrm{~kg} \mathrm{ha}^{-1}$ showed the highest yields on dry canopy weight, $\mathrm{N}$ in the canopy, chlorophyll, and tuber protein at harvest. The minimal nitrogen use efficiency (NUE) was achieved at a dose of $151.84 \mathrm{~N} \mathrm{~kg} \mathrm{ha}^{-1}$. The optimum dose of tuber mineral content was achieved at $138.56 \mathrm{~N} \mathrm{~kg} \mathrm{ha}^{-1}$, namely $5.40 \%$.
\end{abstract}

\section{KEY WORDS}

Nitrogen, potato, protein, efficiency, optimal dosage.

Potatoes (Solanum tuberosum L.) are among the main foodstuffs in demand in the world after wheat, rice, and corn (Reyniers et al., 2020; Saidi \& Hajibarat, 2020). Potato also is one of the most important food crops worldwide but its cultivation is affected by numerous challenges including pests, diseases and high fertiliser requirements which have associated environmental problems (Aloo et al., 2019). Potatoes are consumed as a fresh or processed product that has the potential for food diversification. As a plant that is consumed by its tubers, potato is quite prominent in its nutritional content. The protein and carbohydrates ratio in potato tubers is higher than in plants derived from other cereals and tubers. The amino acids in potato tubers have a balanced composition, which is good for health (Wichrowska \& Szczepanek, 2020a). Leucine, phenylalanine, lysine, valine, arginine, tryptophan, threonine, histidine, and arginine are amino acids found in potatoes. Potatoes contain low fat and cholesterol, but carbohydrates, protein, vitamin $\mathrm{C}$, iron, calcium, and vitamin $\mathrm{B} 6$ are relatively high (Bogucka \& Jankowski, 2020; Kurnianingsih et al., 2020).

The availability of nutrients in the soil will determine the yield and quality of tubers. $\mathrm{N}$ is a very dynamic nutrient (Koch et al., 2020). Uncontrolled N's application will increase farming costs. If plants cannot absorb its presence, it will cause environmental pollution. Moreno et al., 2003; Lerna et al., 2011). Currently, potato fields receive a very high $\mathrm{N}$ intake. In contrast, potatoes have a shallow root system, which creates a high risk of $\mathrm{N}$ loss due to leaching (Neumann et al., 2012). Efforts to maintain high yields and minimize loss of nutrient $\mathrm{N}$ are challenges in potato cultivation.

In potato cultivation production, a relatively high amount of fertilizer is required. Apart from potassium, nitrogen is an essential element and an essential structural component of 
various proteins. At the same time, starch is an essential component of potato tubers, which account for $17 \%-21 \%$ of the tuber's fresh weight. The amount of fertilizer needed is also influenced by soil type, variety, crop rotation, and water supply (Wichrowska \& Szczepanek, 2020). Excessive nitrogen fertilizers cause the accumulation of dry matter on parts of plants other than tubers, increase leaf growth, delay tuber differentiation, the bulking period is delayed, so that tuber yields and tuber dry matter are reduced (Abbasi et al., 2005, Yagi et al., 2020, Fontes et al., 2010). Low $\mathrm{N}$ application can reduce tuber yield and tuber size due to reduced leaf area, shorter tuber initiation period, and increased tuber moisture content resulting in low starch content.

Effective nutrient management is very important for potato farming. Each variety grown in an area requires a specific number of nutrients. An adequate amount of $\mathrm{N}$ will increase the number of roots and shoots, and tuber size. Loss of $\mathrm{N}$ can occur through washing, evaporation, denitrification, utilization by weeds, erosion by water flow, and sedimentation (Shadrack et al., 2016). Determination of nitrogen rates related to nitrogen use efficiency is essential to maximize farm profits by reducing waste of resources or production costs and ultimately reducing environmental pollution (Powel et al., 2010). Nitrogen use efficiency is a yield-determining parameter that can be calculated using either the amount of nitrogen extracted or nitrogen used for tuber formation. Besides, food consumption fulfillment will be better if the materials consumed also contain some minerals needed by the body as additional nutritional intake.

Research on nitrogen dosage on $\mathrm{N}$ efficiency in various plants has been carried out in several countries, including (Aloo et al., 2019; Gholipouri \& Kandi, 2012; Karimov, 2013; Saidi \& Hajibarat, 2020). In the potato crop has been done by (Assunção et al., 2020; Gholipouri \& Kandi, 2012; lerna et al., 2011). In this study, two objectives were set: to analyze the efficiency of $\mathrm{N}$ fertilizer use and to analyze the optimum $\mathrm{N}$ dose, which could increase the protein content of potato tubers. The research was conducted on farmers' land in the village of Sumberejo - Batu, East Java, at an altitude of 710 above sea level. The study used a randomized block design (RBD) with four $\mathrm{N}$ dosage treatments, namely: 40, 80, 120, $160 \mathrm{~N} \mathrm{~kg} \mathrm{ha-1}$. The treatment was repeated six times, with each replication consisting of 5 plant samples. The source of $\mathrm{N}$ fertilizer comes from ZA, which is applied two times, at the same time as planting time and on the 35th day after planting. The research results are expected to obtain information on $\mathrm{N}$ fertilizers' efficient use and find the optimum dosage that can give the highest potato production as indicated by the Nitrogen Use Efficiency (NUE). Besides that, the optimum dose of potato tuber protein content was also obtained. The results are expected to become a policy reference to increase potato production in East Java, Indonesia.

\section{MATERIALS AND METHODS OF RESEARCH}

The research was carried out experimentally on farmers' land in the village of Sumberejo - Batu with an altitude of $690 \mathrm{~m}$ above sea level, an average temperature of $21^{\circ}$ C, $89 \%$ humidity, and clay textured soil. Genotypes of potato grown At 4 . Soil and plant analysis was carried out at the Chemistry Laboratory of the Muhammadyah University of Malang and the Laboratory of Soil and Plants of the Karangploso Agricultural Research and Development Agency.

The tools used: sprayer, analytical scale, measuring cup, meter, oven, calipers, spectrophotometer, glass beaker, dropper pipette, filter paper, burette, measuring flask, glass funnel, chlorofilmeter SPAD Minolta 502, volumetric pipette, and tools for analysis of the protein content of potato tubers. The materials used were: chicken manure, rice straw for mulch, furadan, broccoli waste, paclobutrazol, ZA fertilizer, SP-36, $\mathrm{KCl}$, and chemicals soil analysis, potato tuber starch content analysis.

The study used a simple randomized block design (Rancangan Acak Lengkap/RAK), which consisted of four doses of nitrogen fertilizer, namely: D1 $=40,80,120$, and $160 \mathrm{~N} \mathrm{~kg}$ ha-1. Each treatment was repeated six times, and each treatment in the replication contained five plant samples. The potato seeds planted came from G1, which already had $\pm 2 \mathrm{~cm}$ 
shoots and $20-30 \mathrm{~g} /$ tuber weight. Organic chicken manure is spread evenly on the mounds at a dose of $15 \mathrm{t}$ ha-1, while broccoli waste is given by chopping $\pm 2-3 \mathrm{~cm}$ at a dose of $5 \mathrm{t}$ ha-1. Chicken manure is given ten days before planting, while broccoli waste is given one week before planting. The spacing used is $30 \times 60 \mathrm{~cm}$. Inorganic fertilizers are given two times, namely as basic fertilizer (1/2 dose of N (Za), SP-36 $100 \mathrm{~kg}$ ha-1 and K2O $75 \mathrm{~kg}$ ha-1) and as additional fertilizers are given when the plants are 35 days after planting ( $1 / 2$ dose of $\mathrm{N}(\mathrm{Za})$, SP-36 $50 \mathrm{~kg}$ ha-1 and $\mathrm{K} 2 \mathrm{O} 75 \mathrm{~kg}$ ha-1). Plants are maintained intensively and watered by frying. Rice straw was used as mulch, which was given by spreading it on an experimental plot with a thickness of $5 \mathrm{~cm}$ and given at seven days after planting. Paclobutrazol is given when the plants are 28 days after planting with a concentration of 0.2 $\mathrm{g} \mathrm{l}-1$. The spray volume is $15 \mathrm{ml}$ per plant. Spraying is carried out on all leaves evenly. The variables observed in this experiment included: leaf number, total chlorophyll, crown dry weight, shoot $\mathrm{N}$, tuber $\mathrm{N}$, dry tuber weight, nitrogen uptake efficiency, and tuber protein.

Data analysis used the $\mathrm{F}$ test following the design used. If there is a real effect, then proceed with the BNJ test at the 5\% level. Regression analysis was used to determine the optimal fertilizer dosage using Minitab 16. The variables analyzed in this research were leaf number, total chlorophyll, dry crown weight, shoot $\mathrm{N}$, tuber $\mathrm{N}$, dry tuber weight, nitrogen uptake efficiency, and tuber protein.

\section{RESULTS AND DISCUSSION}

The results of observing the number of leaves at the age of 61 days after planting showed that the administration of various doses of $\mathrm{N}$ had a significant effect $(p \geq 0.05)$ (Table 1). The number of leaves tended to increase with the increasing dose of $\mathrm{N}$ applied. However, the application of 80,120 , and $160 \mathrm{~N} \mathrm{~kg} \mathrm{ha}^{-1}$ resulted in the number of leaves that were not significantly different, with results of $274.92,298.92$, and 305.08 strands.

The results of chlorophyll observations on the leaves of potato plants aged 35 days after planting showed that the administration of various doses of $\mathrm{N}$ had a significant effect ( $\mathrm{p}$ $\geq 0.05$ ) (Table 1). Leaf chlorophyll increased with increasing $\mathrm{N}$ dose. It can be seen that at a dose of $120 \mathrm{~N} \mathrm{~kg} \mathrm{ha}^{-1}$, it produced 51,740 chlorophyll, which was not significantly different from the $\mathrm{N}$ dose of $160 \mathrm{~N}$ kg ha-1, which was 50,832 .

Table 1 - Number of leaves and chlorophyll

\begin{tabular}{|l|c|c|}
\hline \multicolumn{1}{|c|}{$\mathrm{N}$} & Number of Leaves & Chlorophyll \\
\hline & & \\
\hline $40 \mathrm{~kg} \mathrm{~N} \mathrm{ha}-1$ & $228.50 \mathrm{a}$ & $46.263 \mathrm{a}$ \\
\hline $80 \mathrm{~kg} \mathrm{~N} \mathrm{ha}-1$ & $274.92 \mathrm{ab}$ & $48.993 \mathrm{~b}$ \\
\hline $120 \mathrm{~kg} \mathrm{~N}$ ha-1 & $298.92 \mathrm{~b}$ & $51.740 \mathrm{c}$ \\
\hline $160 \mathrm{~kg} \mathrm{~N}$ ha-1 & $305.08 \mathrm{~b}$ & $50.832 \mathrm{bc}$ \\
\hline BNJ 5\% & 67.06 & 2.086 \\
\hline
\end{tabular}

Note: Numbers accompanied by different letters in the same column shows a significant difference in the BNJ test \%.

The results showed that the administration of various $\mathrm{N}$ doses significantly affected dry shoot weight and dry tuber weight produced at harvest (Figure 1). Treatment N $160 \mathrm{~N} \mathrm{~kg} \mathrm{ha-}$ 1 showed the highest crown dry weight per plant compared to other treatments, with a yield of $21,865 \%$. Treatment $\mathrm{N} 40 \mathrm{~N} \mathrm{~kg} \mathrm{ha-1}$ showed the lowest canopy dry weight per plant, namely $8.885 \%$. The tubers' dry weight showed the lowest yield at a dose of $\mathrm{N} 40 \mathrm{~N} \mathrm{~kg} \mathrm{ha}^{-1}$, amounting to $14,352 \%$ and significantly different from other $\mathrm{N}$ dose treatment.

The results showed that the administration of various $\mathrm{N}$ doses had a significant effect on the $\mathrm{N}$ content in the shoots and $\mathrm{N}$ in the tubers (Figure 2). Increasing the $\mathrm{N}$ dose applied to the $\mathrm{N}$ dose of $120 \mathrm{~N} \mathrm{~kg} \mathrm{ha}^{-1}$ would increase the canopy's $\mathrm{N}$ content. However, if the $\mathrm{N}$ dose were increased to $160 \mathrm{~N} \mathrm{~kg} \mathrm{ha}{ }^{-1}$, it would not increase the canopy's $\mathrm{N}$ level. The $\mathrm{N}$ content in the highest canopy was obtained at $5.607 \%$. It was not significantly different if the $\mathrm{N}$ dose was added with the result of $5.624 \%$. The results of NUE observations show that the 
lower the dose of $\mathrm{N}$ applied, the NUE value will increase. Applications of N 120 and $160 \mathrm{~N} \mathrm{~kg}$ ha $^{-1}$ showed the lowest values, namely 0.930 and $0.590 \%$, respectively.

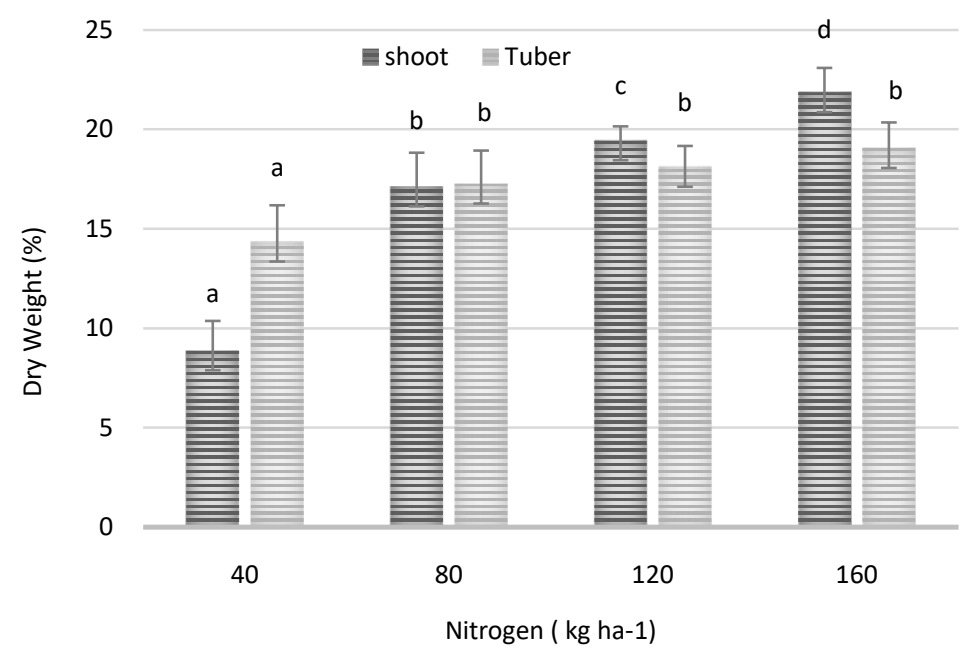

Figure 1 - Canopy and tuber dry weight at various doses of $\mathrm{N}$

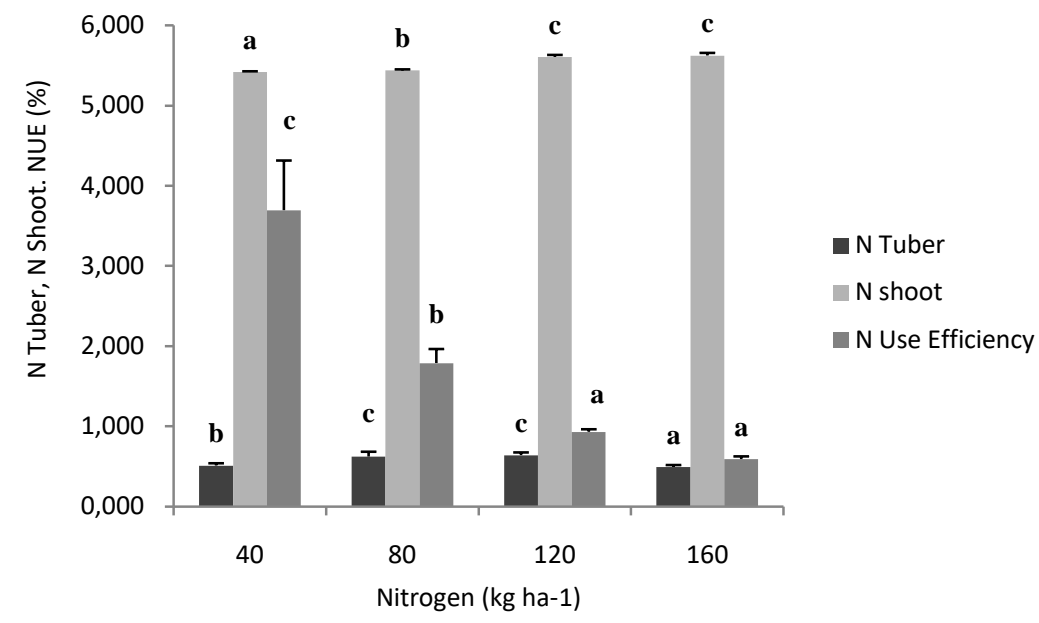

Figure 2 - Tuber N, N Shoot and NUE at Various N Doses

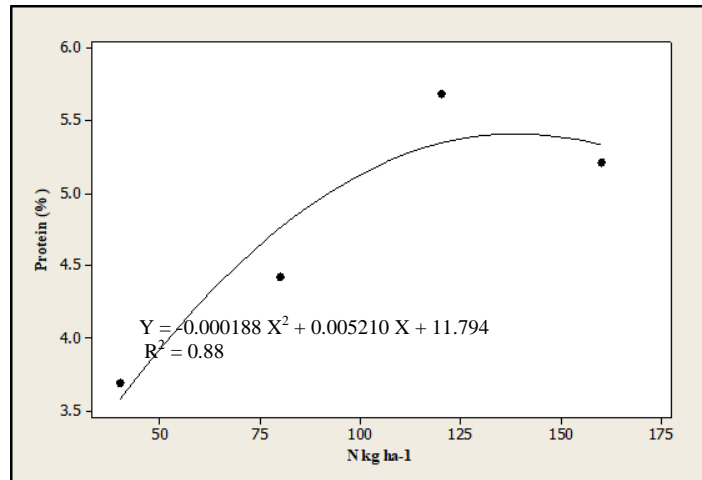

A

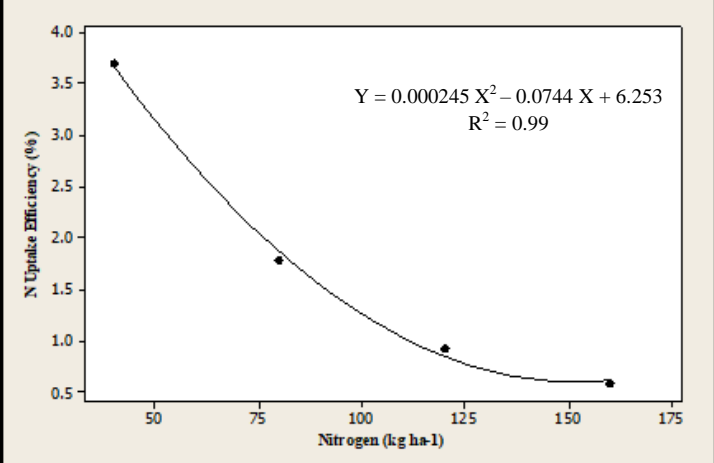

B

Figure 3 - The relationship between $\mathrm{N}$ dose application and tuber protein content $(\mathrm{A})$ and $\mathrm{N}$ and NUE dosage application (B)

Figure $3 \mathrm{~A}$ shows the relationship between $\mathrm{N}$ dose application and tuber protein content at harvest. With the $\mathrm{N}$ dose application, which is greater up to $120 \mathrm{~N} \mathrm{~kg} \mathrm{ha}^{-1}$, the tuber 
protein content will increase. However, if the $\mathrm{N}$ fertilizer dose is added to $120 \mathrm{~N} \mathrm{~kg} \mathrm{ha}^{-1}$, it will not affect tuber protein. Through the equation $Y=-0.000188 \times 2+0.005210 x+1.794$, the optimum dose is $138.564 \mathrm{~N} \mathrm{~kg} \mathrm{ha}^{-1}$ which can produce a maximum protein content of $5.40 \%$. Figure 3B shows the relationship between $\mathrm{N}$ dose application and NUE. The application of higher $\mathrm{N}$ doses up to $160 \mathrm{~N} \mathrm{~kg} \mathrm{ha}{ }^{-1}$ tended to reduce NUE. Through equation $\mathrm{Y}=0.000245$ $\mathrm{x} 2-0.744 \mathrm{x}+6.253$, the minimum NUE is achieved in applying $151.84 \mathrm{~N} \mathrm{~kg} \mathrm{ha}^{-1}$.

The application of larger $\mathrm{N}$ doses to the limit of $\mathrm{N} 120 \mathrm{~N} \mathrm{~kg} \mathrm{ha}^{-1}$ will increase plant leaves and chlorophyll. This can be understood because nitrogen has a role in the formation of plant tissue. Nitrogen is an essential structural component to form chlorophyll and various proteins (Gholipouri \& Kandi, 2012; Shunka et al., 2017). Low N supply not only reduces growth but affects tuber size due to reduced leaf number and area. A higher level of $\mathrm{N}$ has a positive effect on the growth variable. It increases the number and yield of tubers. This is associated with more leaves. Photosynthesis will be more active, and photosynthate can be transferred to the tubers (Kumar et al., 2007)(Assunção et al., 2020). Appropriate $N$ application is needed to optimize potato yield and quality. According to Jatav et al. (2017), giving $\mathrm{N}$ has a significant effect on growth parameters. A similar result was obtained by Kolodziejczyk (2014). N application led to a significant increase in the productivity of potato plants compared to smaller doses.

The increase in the number of leaves increases the leaf area of the plant. It does not always end with an increase in the organ's dry weight, which is economically valuable. Leaves are not only a producer of photosynthate but also as users of photosynthate. Photosynthate will be allocated first to the crown and the next to the economically valuable plant. This can be seen in the observation of the dry weight of the tubers. The dry weight of the tubers increased when the fertilizer dose was increased to $80 \mathrm{~N} \mathrm{~kg} \mathrm{ha}^{-1}$. Furthermore, if it were increased to $160 \mathrm{~N} \mathrm{~kg} \mathrm{ha}^{-1}$, it would not increase the tubers' dry weight. This occurs because the higher $\mathrm{N}$ application results in the accumulation of dry matter in other parts of the plant, an increase in the number and area of leaves, inhibition of tuber differentiation, delayed bulb enlargement period, finally, the yield of tubers and tuber dry matter decreases (Yagi et al., 2020)(Abbasi et al., 2005; Fontes et al., 2010).

$\mathrm{N}$ is added through fertilizers to achieve maximum results. Efficiency can be improved by knowing the actual plant $\mathrm{N}$ nutrient requirements (Gholipouri \& Kandi, 2012; Wichrowska \& Szczepanek, 2020). Observation of crown $\mathrm{N}$ content showed that doses of $120 \mathrm{~N} \mathrm{~kg} \mathrm{ha}$ ${ }^{1}$ and $160 \mathrm{~N} \mathrm{~kg} \mathrm{ha}^{-1}$ resulted in high crown $\mathrm{N}$. Meanwhile, $\mathrm{N}$ tubers tend to decrease when the $\mathrm{N}$ dose is increased to $160 \mathrm{~N} \mathrm{~kg} \mathrm{ha}^{-1}$. Many factors and processes influence the relationship between $\mathrm{N}$ uptake and availability, including the initial amount of $\mathrm{N}$ before planting, immobilization, denitrification, washing, and evaporation. In agricultural production systems, nitrogen leaching can reach 50 - 75\% (Asghari and Cavagnaro, 2011). This can affect human health as a result of water pollution (Umar and lqbal, 2007). Besides, soil pH, texture, drought, and waterlogging conditions. In general, higher $\mathrm{N}$ applications will increase high dry matter and high $\mathrm{N}$ content. Also, it was found that increasing the dose of $\mathrm{N}$ would increase the protein content of tubers. The results obtained are in line with what Abu-Zinada (2009) did. In NUE observations, high results were obtained from N's application at a low dose (40 N $\mathrm{kg} \mathrm{ha}^{-1}$ ). These results are consistent with the findings of Kakuhenzire et al. (2005). The same thing was conveyed by Bertrand et al. (2011), which stated that it is important to measure NUE to determine excessive fertilizer application while still paying attention to the yields that have economic value so that they provide good benefits for farmers. The strategy that can be done to increase NUE's value is to choose the varieties to be planted (Hirel et al., 2007) because NUE has specific characteristics for varieties (genotypes).

\section{CONCLUSION}

This study describes the optimal dosage and fertilizer management to increase the protein content of potato tubers. The field research was conducted on a farmer's land in the village of Sumberejo, Batu, East Java, Indonesia. The study used a randomized block design (Rancangan Acak Kelompok/RAK) with four N dosage treatments, namely: 40, 80, 120, 160 
$\mathrm{N} \mathrm{kg} \mathrm{ha-1}$. The treatment was repeated six times, with each replication consisting of 5 plant samples. The source of $\mathrm{N}$ fertilizer comes from $\mathrm{ZA}$, which is applied twice. The results of the study have a significant effect on all observed variables. Application of $\mathrm{N} 160 \mathrm{~N} \mathrm{~kg} \mathrm{ha}^{-1}$ will increase leaf chlorophyll, $\mathrm{N}$ crown, and tuber protein. The higher the $\mathrm{N}$ application, the lower the NUE (Nitrogen use efficiency) value. The minimum NUE was achieved at a dose of $151.84 \mathrm{~N} \mathrm{~kg} \mathrm{ha}^{-1}$. The optimum dose of tuber protein content was achieved at the provision of $138.56 \mathrm{~N} \mathrm{~kg} \mathrm{ha}^{-1}$ of $5.40 \%$.

\section{ACKNOWLEDGMENTS}

The authors would like to thank the Ministry of Research and Technology/National Research and Innovation Agency for funding assistance for the Higher Education Leading Applied Research (PTUPT) scheme for the 2020 Fiscal Year and all parties who have helped implement this research.

\section{REFERENCES}

1. Abbasi, A., A. Tobeh, R. Asghari Zakariya, A. Hosseinzadeh and A. Aghazadeh. 2005. Study of $\mathrm{N}$ intake and efficiency in potato tubers at different $\mathrm{N}$ fertilizer levels. Proceedings of 9th International Agriculture and Plant Breeding Conference. University of Tehran. pp: 143.

2. Abu-Zinada IA. 2009. Potato response to potassium and nitrogen fertilization under gaza strip conditions. J. Al Azhar University-Gaza (Nat. Sciences), 11:15-30.

3. Asgar, A. 2017. Kualitas umbi beberapa klon kentang (Solanum tuberosum L.) dataran medium untuk keripik. J. Berita Biologi 12 (1): 29-37.

4. Asghari HR, Cavagnaro TR. 2011. Arbuscular mycorrhizas enhance plant interception of leached nutrients. Funct. Plant Biol. 38:219-226.

5. Aloo, B. N., Mbega, E. R., \& Makumba, B. A. (2019). Rhizobacteria-based technology for sustainable cropping of potato (Solanum tuberosum L.). Potato Research, 1-21.

6. Assunção, N. S., Fernandes, A. M., Soratto, R. P., Mota, L. H. S., Ribeiro, N. P., \& Leonel, M. (2020). Tuber Yield and Quality of Two Potato Cultivars in Response to Nitrogen Fertilizer Management. Potato Research, 1-20.

7. Fontes, PCR, Braun, H., Bussato, C., Cecon, PR. 2010. Economic optimum nitrogen fertilization rates and nitrogen fertilization rate effects on tuber characteristic of potato cultivars. Potato Res., 53, 167 - 179.

8. Hirel B, Le Gouis J, Ney B, Gallais A. 2007. The challenge of improving nitrogen use efficiency in crop plants: Towards a more central role for genetic variability and quantitative genetics within integrated approaches. J. Exp. Bot. 58:2369-2387.

9. Gholipouri, A., \& Kandi, M. A. S. (2012). Evaluating of nitrogen use efficiency's as affected by different nitrogen fertilizers levels on potato varieties. Advances in Environmental Biology, 774-779.

10. Ierna, A., Pandino, G., Lombardo, S., \& Mauromicale, G. (2011). Tuber yield, water and fertilizer productivity in early potato as affected by a combination of irrigation and fertilization. Agricultural Water Management, 101(1), 35-41.

11. Kakuhenzire R, Hakiza JJ, Berga L, Adipala E, Olanya M, Wagoire W, Shunka I. 2005. Response of four selected potato cultivars to fungicide and fertilizer application. African Crop Science Conference Proceedings, 6:69-75.

12. Karimov, A. (2013). Productive efficiency of potato and melon growing farms in Uzbekistan: A two stage double bootstrap data envelopment analysis. Agriculture, 3(3), 503-515.

13. Kolosa, KM. 1993. The potato and human nutrition. American Potato Journal 70 (5): 375 $-383$.

14. Koch, M., Naumann, M., Pawelzik, E., Gransee, A., \& Thiel, H. (2020). The importance of nutrient management for potato production Part I: Plant nutrition and yield. Potato Research, 63(1), 97-119. 
15. Kumar, P., Pandey, S. K., Singh, B. P., Singh, S. V., Kumar, D. 2007. Effect of nitrogen rate on growth, yield, economics and crisps quality of Indian potato processing cultivars. Potato Res., 50, 143-155.

16. Moreno, A., Moreno, MM, Ribas, F., Cabello, MJ. 2003. Influence of nitrogen fertilizer on grain yield of barley (Hordeum vulgare L.) under irrigated conditions. Spanish J. Res., 1 (1): 91-100.

17. Neumann, A., Torstensson, G., Aronsson, H. 2012. Nitrogen and phosphorus leaching losses from potatoes with different harvest times and following crops. Field Crop Res., 133, 130-138.

18. Pack JE, Hutchinson CM, Simonne EH. 2006. Evaluation of controlledrelease fertilizers for northeast Florida chip potato production. J. Plant Nutr. 29:1301-1313.

19. Powell JM, Gourley CJP, Rotz CA, Weaver DM. 2010. Nitrogen use efficiency: A potential performance indicator and policy tool for dairy farms. Environ. Sci. Policy 13:217-228.

20. Saeedi, M. 2007. Study of effect of tuber size and N fertilizer on potato growth indices and its tubers quantity and quality. M.Sc. Thesis. University of Mohagheghe Ardabili, Ardabil, Iran, pp: 119.

21. Shadrack Nyawade, Gachene C, Nancy K, Schulte GE. 2016. Effect of potato (Solanum tuberosum L.) cropping system on soil and nutrient losses through run-off in a humicnitisol. Kenya. Geophysical Research Abstracts. Vol. 18. EGU 2016 - 6629 - 1. Nairobi. Kenya.

22. Shunka, A., Abebe C, Gebremedhin, Ebrahim S, Lemma T,. 2017. Effect of nitrogen and potassium application rates on nitrogen use efficiency and tuber minerals content in central high lands of Ethiopia. Journal of Horticulture and Forestry 9(1):1-8.

23. Umar AS, lqbal M. 2007. Nitrate accumulation in plants, factors affecting the process, and human health implications. A review. Agron. Sustain. Dev. 27:45-57.

24. Westerman, D. T. 2005. Nutritional requirements of potatoes. Ame. J. Potato Res., 82, 301-307.

25. Reyniers, S., Ooms, N., Gomand, S. V., \& Delcour, J. A. (2020). What makes starch from potato (Solanum tuberosum L.) tubers unique: A review. Comprehensive Reviews in Food Science and Food Safety, 19(5), 2588-2612.

26. Saidi, A., \& Hajibarat, Z. (2020). Application of Next Generation Sequencing, GWAS, RNA seq, WGRS, for genetic improvement of potato (Solanum tuberosum L.) under drought stress. Biocatalysis and Agricultural Biotechnology, 101801.

27. Shunka, E., Chindi, A., Seid, E., \& Tessema, L. (2017). Effect of nitrogen and potassium application rates on nitrogen use efficiency and tuber minerals content in central high lands of Ethiopia. Journal of Horticulture and Forestry, 9(1), 1-8.

28. Singh, S. K., Srivastava, S., \& Chauhan, S. (2020). Inequality in child undernutrition among urban population in India: A decomposition analysis. BMC Public Health, 20(1), $1-15$.

29. Wichrowska, D., \& Szczepanek, M. (2020). Possibility of Limiting Mineral Fertilization in Potato Cultivation by Using Bio-Fertilizer and Its Influence on Protein Content in Potato Tubers. Agriculture, 10(10), 442.

30. Yagi, R., Nazareno, N. R. X. de, \& Soratto, R. P. (2020). Agronomic and Economic Interactions between Sidedressed Nitrogen and Potassium Fertilizations on 'Atlantic'Potato. Brazilian Archives of Biology and Technology, 63. 